кандидат педагогічних наук, доцент

(Житомирський державний університет імені Івана Франка) pavnad@ukr.net

ORCID: $0000-0003-2601-4104$

\title{
ЕКСПЕРТНА ОЦІНКА РЕЗУЛЬТАТИВНОСТІ НЕФОРМАЛЬНОЇ ОСВІТИ У ПРОФЕСІЙНІЙ ПІДГОТОВЦІ МАЙБУТНІХ СОЦІАЛЬНИХ ПЕДАГОГІВ
}

У статті представлено результати експертної оцінки ролі неформальної освіти у фаховій підготовці майбутніх соиіальних педагогів за шкалами: значення неформальної освіти у професійному становленні експертів; визначення ефективності форм і методів неформальної освіти; характеристика забезпечення формування функиіональної моделі майбутніх фахівців сочіальної сфери. Сформульовано висновок щุодо емпіричного підтвердження науково обтрунтованих характеристик неформальної освіти: практико-оріснтованості, постійності та неперервності впливу.

Ключові слова: неформальна освіта, експертна оцінка, експертиза, функціональна модель, майбутні соиіальні педагоги.

Процес професійної підготовки майбутніх соціальних педагогів з позиції компетентнісного підходу визначається основним очікуваним результатом - набуттям майбутніми фахівцями професійної компетентності як комплексної здатності до розв'язання фахових завдань. Водночас, поза увагою формальної системи професійної освіти залишається проблема врахування додаткових освітніх впливів, визначених як індивідуальними інтересами молоді, так і соціальними змінами щодо професійних вимог і здатностей. Зростання ролі неформальної освіти як умови забезпечення навчання впродовж життя вимагає наукового обгрунтування й емпіричних досліджень щодо ролі неформальної освіти у професійному становленні фахівців. Важливим напрямком розв'язання означеної вимоги часу є оцінка результатів неформального навчання у соціальній сфері.

Аналіз дисертаційних досліджень щодо організації процесу професійної підготовки майбутніх соціальних педагогів свідчить про переважання теоретико-практичних розробок у конкретизованих предметах дослідження, напрямах майбутньої професійної діяльності, як-от: використання казкотерапії (О. В Філь, 2010), застосування особистісно орієнтованих технологій (О. Г. Платонова, 2010), організації фізкультурно-оздоровчої діяльності (А. Д. Ведмедюк, 2011), профілактики наркотичної залежності (О.В.Тютюнник, 2010), профілактично-корекційної діяльності (М. М. Ярошко, 2011), роботи із сім'єю (О. Г. Луганцева, 2011), формування валеологічної грамотності (Л. З. Пакушина, 2010), тощо. Означені дослідження характеризуються розробкою авторами діагностичного інструментарію дослідної роботи й вивченням результатів професійної підготовки 3 огляду на проблему дослідження. Системно результативність процесу професійної підготовки майбутніх соціальних педагогів частково висвітлена у дисертаціях І. І. Доброскок (2011) щодо теорії та практики організації навчальної діяльності, Я. В. Кічук (2010) щодо засад формування правової компетентності. Водночас, недостатньо вивченими залишаються питання результативності процесу професійної підготовки майбутніх соціальних педагогів із урахуванням впливу усіх чинників ефективності, у т.ч. неформальної освіти як основної умови безперервного особистісно орієнтованого розвитку.

Відповідно, метою статті є висвітлення результатів експертного оцінювання результативності неформальної освіти у професійній підготовці майбутніх соціальних педагогів. Завдання дослідження: охарактеризувати значення неформальної освіти у професійному становленні експертів соціальної сфери; визначити ефективність окремих форм і методів неформальної освіти; охарактеризувати вплив формальної і неформальної освіти на функціональну модель професійної діяльності майбутніх фахівців соціальної сфери.

Методологія, методи та зміст експертного оцінювання ролі неформальної освіти у фаховій підготовці майбутніх соціальних педагогів описані нами у статті [1]. Охарактеризуємо одержані результати експертної оцінки.

Всього у опитуванні взяли участь 39 респондентів; відповідно до обраних автором критеріїв компетентності діапазон допустимих значень рівня компетентності для врахування результатів опитування становить від 0,5 до 1 балів. До цього діапазону, згідно з результатами самооцінки, включено 24 експерти, чиї відповіді були прийняті як експертні оцінки 3 проблеми дослідження (наукова експертиза). Однак, ми використовували порівняння результатів опитування учасників наукової

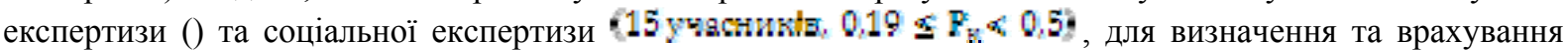
відмінностей у оцінках експертів із науковим стажем та високим рівнем громадської активності.

Розподіл експертів за місцем проживання (у дужках вказано кількість учасників, перша цифра наукова експертиза, друга цифра - соціальна експертиза) свідчить про достатньо широкі територіальні 
межі дослідження, що дозволяє зробити результати оцінювання більш валідними, незалежними від регіону та типу поселення.

- Бердичів (1 / 0);

- Вінниця (2 / 3);

- Житомир (4 / 6);

- Івано-Франківськ (3 / 0);

- Київ (6 / 1);

- Київська обл. (0 / 1);

- Коростишів $(0 / 1)$;

- Львів $(1 / 0)$;

- Ніжин (3 / 0);

- Новоград-Волинський (0 / 2);
- Старобільськ (2 / 0);

- Суми (1 / 0);

- Харків (1/1).

Таким чином, експертна група характеризується достатнім досвідом роботи у сфері неформальної освіти та досвідом професійної підготовки майбутніх фахівців соціальної сфери, наявністю наукових та науково-популярних публікацій із проблеми дослідження, високою соціальною та громадською активністю та представляє різні регіони України.

Значення неформальної освіти у професійному становленні експертів вивчалося нами задля визначення ролі та характеру участі впливу неформальної освіти на побудову кар'єри у соціальній сфері.

На запитання про досвід участі у неформальній освіті були одержані такі відповіді: "Так, постійно" 16 / 7; "Так, час від часу" - 8 / 7; "Так, але рідко" - 0 / 0; "Ні, такого досвіду не маю" - 0 / 1.

Як видно із результатів, серед експертів, які взяли участь у опитуванні (наукова експертиза) не має жодного, хто б не мав досвіду участі у неформальній освіті. Переважна більшість експертів $(67 \%)$ постійно беруть участь у неформальному навчанні. Серед опитаних, яких не віднесено до експертної групи за об'єктивними показниками, 47 \% постійно навчаються у системі неформальної освіти; 47 \% мають досвід неформального навчання час від часу.

Таким чином, роль неформальної освіти для забезпечення власного фахового й особистісного зростання є вкрай високою, вона визначає статус людини у науковому, громадському, соціальному секторах та на сьогодні $є$ необхідною вимогою професійної самореалізації.

Характер цього впливу на окремі професійно значущі риси соціальної активності експертів представлено у табл. 1 .

Оцінка впливу неформальної освіти на власний особистісний та професійний розвиток

Таблиия 1. експертів*

\begin{tabular}{|l|l|l|l|c|}
\hline \multirow{2}{*}{ № } & \multicolumn{1}{|c|}{ Сфери } & $\begin{array}{l}\text { Наукова } \\
\text { експертиза }\end{array}$ & $\begin{array}{l}\text { Соціальна } \\
\text { експертиза }\end{array}$ & $\begin{array}{l}\text { Експертне } \\
\text { опитування } \\
\text { загалом }\end{array}$ \\
\hline 1 & Професійні компетенції & 4,33 & 4,53 & 4,41 \\
\hline 2 & Громадська ініціативність і активність & 4,42 & 4,40 & 4,41 \\
\hline 3 & Здатність до сталого особистісного зростання & 4,46 & 4,60 & 4,51 \\
\hline 4 & Ціннісно-мотиваційна сфера & 4,25 & 4,40 & 4,31 \\
\hline 5 & Афективно-чуттєва сфера & 3,92 & 4,13 & 4,00 \\
\hline 6 & Когнітивно-гносеологічна сфера & 4,33 & 4,20 & 4,28 \\
\hline 7 & Практично-діяльнісна сфера & 4,71 & 4,60 & 4,67 \\
\hline
\end{tabular}

* Оиінювання за 5-ти бальною шкалою, де 1 - найнижчий бал, 5 - найвищий; у таблиці представлено середні показники

Отже, найвище експертами оцінено вплив неформального навчання на розвиток практичнодіяльнісної сфери (середній бал 4,71; в узагальнених даних обох груп - 4,67 бали). Тобто, найвищий вплив неформальна освіта має саме на формування умінь, навичок і досвіду діяльності.

Друге рейтингове місце посідає вплив неформальної освіти на здатність людини до сталого особистісного зростання (4,46 балів у науковій експертизі, 4,51 бали за загальними результатами опитування). Тобто, окрім професійного вдосконалення, участь у неформальній освіті дає можливість учасникам задовольнити потреби особистісного зростання, розвитку, самовдосконалення.

Загалом, результати опитування підтвердили 2 провідні характеристики неформальної освіти, описані у науковій літературі й підтверджені емпірично: 1) іiі практико-орієнтованість (відповідність фаховим потребам та надання інструментів для підвищення ефективності діяльності); 2) постійність та неперервність впливу на особистісне зростання учасників, яке ми пов'язуємо з забезпеченням потреби людини у позитивному самоприйнятті, самоповазі, саморозвитку.

Такі результати неформальної освіти забезпечуються дотриманням іiі провайдерами правил i характерологічних ознак, висвітлених нами при теоретичному аналізі проблеми дослідження та у авторській концепції.

Оцінювання ефективності форм і методів неформальної освіти здійснювалося нами за методикою попарних порівнянь, яка дозволяє побудувати рейтинг ефективності форм і методів неформальної освіти не стільки базуючись на привабливості методу, скільки на основі компаративного аналізу його результативності у порівнянні з іншими. Дані експертної оцінки форм і методів неформальної освіти висвітлено у табл. 2 . 
Рейтинг результативності форм і методів неформального навчання у соціальній сфері

Таблиия 2.

\begin{tabular}{|c|c|c|c|c|}
\hline № & Форми і методи & $\begin{array}{l}\text { Наукова } \\
\text { експертиза }\end{array}$ & $\begin{array}{l}\text { Соціальна } \\
\text { експертиза }\end{array}$ & $\begin{array}{l}\text { Експертне } \\
\text { опитування } \\
\text { загалом }\end{array}$ \\
\hline 1 & Тематичні табори & 11.13 & 12,47 & 11,64 \\
\hline 2 & $\begin{array}{l}\text { Форум-театри, інтерактивні театри, плей-бек } \\
\text { театри }\end{array}$ & 11.00 & 13,53 & 11,97 \\
\hline 3 & Відкриті університети & 10.33 & 11,53 & 10,79 \\
\hline 4 & Фахові змагання та конкурси & 10.13 & 11,73 & 10,74 \\
\hline 5 & Організація / участь у громадських рухах & 9.17 & 9,47 & 9,28 \\
\hline 6 & $\begin{array}{l}\text { Організація фестивалів, концертів, } \\
\text { культурно-мистецьких акцій }\end{array}$ & 9.00 & 8,27 & 8,72 \\
\hline 7 & Обмін досвідом & 8.71 & 9,20 & 8,90 \\
\hline 8 & Ініціювання та втілення соціальних проектів & 7.67 & 7,20 & 7,49 \\
\hline 9 & $\begin{array}{l}\text { Ведення просвітницької роботи серед } \\
\text { населення }\end{array}$ & 6.75 & 6,33 & 6,59 \\
\hline 10 & Спілкування з фахівцями & 6.50 & 5,93 & 6,28 \\
\hline 11 & $\begin{array}{l}\text { Досвід практичної діяльності у якості } \\
\text { волонтера }\end{array}$ & 6.00 & 5,60 & 5,85 \\
\hline 12 & Відвідування музеїв, бібліотек, галерей, тощо & 5.75 & 5,33 & 5,59 \\
\hline 13 & Участь у об'єднаннях за інтересами & 5.21 & 3,60 & 4,59 \\
\hline 14 & $\begin{array}{l}\text { Відвідування довготривалих курсів, шкіл, } \\
\text { тренінгових програм }\end{array}$ & 5.08 & 4,07 & 4,69 \\
\hline 15 & Читання літератури за фахом & 4.00 & 2,60 & 3,46 \\
\hline 16 & $\begin{array}{l}\text { Участь у тренінгах, майстер-класах, } \\
\text { семінарах }\end{array}$ & 3.58 & 3,13 & 3,41 \\
\hline
\end{tabular}

Одержані у ході експертного оцінювання рейтинги результативності окремих форм і методів неформального навчання виявилися для нас неочікуваними з огляду на поширеність й інтерактивність окремих з них.

Так, згідно з результатами наукової експертизи найвищі оцінки результативності одержали форми організації неформальної освіти, які вимагають залучення фахівців, є достатньо довготривалими та системними й відображають дозвіллєвий і / або міждисциплінарний характер освітніх послуг: тематичні табори, різні види соціальних театральних технологій, відкриті університети, фахові змагання та конкурси, участь у громадських рухах та культурних акціях і фестивалях. Це дає нам змогу зробити висновок про важливість поглиблення змісту неформальної освіти та опору на інтереси молоді при іiі організації. Адже означені форми 3 високим рейтингом результативності, на нашу думку, характеризуються, з одного боку, експертністю, глибокою теоретично-практичною базою, зануренням у навчання через спільну діяльність; а з іншого боку - інноваційністю, креативністю, орієнтованістю на власний вибір молоді.

Неочікуваним результатом дослідження виявилася низька оцінка тренінгів, майстер-класів, семінарів як форм неформальної освіти (за оцінками наукової експертизи, за оцінками соціальної експертизи дані дещо різняться). Ми обгрунтовуємо це почасти обезцінюванням, передусім, тренінгової форми діяльності як занадто поширеної, почасти не достатньо фахової, із недотриманням вимог до партисипативності, практико-орієнтованості та рівності. Окрім того, розрізнені тренінги, семінари, майстер-класи, не об'єднані системною метою та протяжністю у часі, не задовольняють вимог експертів щодо якості професійної підготовки майбутніх соціальних педагогів. Це дає підстави припустити, що негативний досвід участі у тренінгах, набутий учасниками, та відсутність професійних меж, здатних відрізняти тренінгове навчання від інших форм організованої групової роботи на практиці знижує роль тренінгів як форм неформального навчання молоді.

Форми те методи неформальної освіти із середніми рейтинговими оцінками (шкали №7-11 табл. 2) характеризуються комунікативністю як здатністю до обміну інформацією, досвідом, емоціями, станами; синергетичним ефектом соціально-педагогічної діяльності та навчання; можливістю побудови соціально значущих міжособистісних зв'язків та партнерів. Тобто, це переважно групові форми неформального навчання (обмін досвідом, ініціювання та втілення соціальних проектів, ведення просвітницької роботи серед населення, спілкування 3 фахівцями, досвід практичної діяльності у якості волонтера), які створюють умови не лише для формування професійної компетентності, але й для міжособистісного самоствердження студентів у середовищі однодумців. На противагу ним, форми й методи, які мають нижчий рейтинговий бал, можуть реалізовуватися як у індивідуальній, так і груповій формі. 
Результати соціальної експертизи ефективності форм і методів неформального навчання суттєво не відрізняються від наукової експертизи окрім значення системної групової освітньої діяльності (довготривалих шкіл, курсів, тренінгових програм, майстерень, семінарів), які мають більш високий рейтинг за результатами оцінки соціальних активістів.

Загалом, проведена оцінка форм і методів дозволяє нам визначити напрями планування соціальноперетворювальної діяльності формувального етапу експерименту.

Дослідження функціональної моделі професійної діяльності майбутніх фахівців соціальної сфери реалізовувалося експертами за трьома шкалами: 1) актуальність окремих функцій соціальнопедагогічної діяльності, 2) потенціал формальної освіти для формування компетентності у виконанні означених функцій, 3) відповідний потенціал неформальної освіти.

Результати оцінювання окремими групами експертів за 5-ти бальною шкалою представлено у таблицях 3-5.

Наукова експертиза функціональної моделі майбутніх соціальних педагогів

Табличя 3.

\begin{tabular}{|c|c|c|c|c|}
\hline № & Функиії & Актуальність & $\begin{array}{c}\text { Потенціал } \\
\text { формальної } \\
\text { освіти }\end{array}$ & $\begin{array}{c}\text { Потенціал } \\
\text { неформальної } \\
\text { освіти }\end{array}$ \\
\hline 1 & Адвокативна & 4,50 & 2,96 & 4,13 \\
\hline 2 & Анімаційна & 3,96 & 3,13 & 4,50 \\
\hline 3 & Діагностична & 4,67 & 3,71 & 4,00 \\
\hline 4 & Консультаційна & 4,63 & 3,50 & 4,21 \\
\hline 5 & Медіаторська & 4,58 & 3,08 & 4,42 \\
\hline 6 & Патронажна & 4,38 & 3,42 & 4,08 \\
\hline 7 & Терапевтична & 4,13 & 3,17 & 3,96 \\
\hline 8 & Управлінська & 4,13 & 2,83 & 3,92 \\
\hline 9 & Фасилітативна & 4,71 & 3,04 & 4,29 \\
\hline & Середнє & 4,41 & 3,20 & 4,17 \\
\hline
\end{tabular}

Як видно із результатів опитування, найвище науковцями оцінено фасилітативну (4,71 бали) та діагностичну функції соціально-перетворювальної діяльності (4,67 бали).

Висока оцінка значення фасилітативної функції визначається, на нашу думку, специфікою соціальноперетворювальної діяльності, яка вимагає від ії провайдера супроводу ефективної комунікації суб'єктів соціальної сфери для прояснення й досягнення визначених цілей [2]. Тобто, саме фасилітація соціальних процесів на сьогодні, на думку експертів, є найбільш актуальною функцією соціальної роботи та соціально-педагогічної діяльності.

Високе значення діагностичної функції ми обгрунтовуємо необхідністю первинної соціальної діагностики для прийняття майбутніми фахівцями правильних рішень та здійснення відповідної соціальному діагнозу професійної діяльності.

Найнижче експертами оцінено необхідність підготовки майбутніх фахівців соціальної сфери до реалізації анімаційної функції (3,96 бали). Ми це пояснюємо почасти з різницею у тлумаченні анімації. 3 одного боку, анімація розглядається як метод підтримки, активізації та вдосконалення механізмів співпраці суб'єктів і середовища [2]. 3 іншого боку, анімація часто розглядається суто як соціокультурна технологія, спрямована на культурно-дозвіллєву діяльність соціальних груп [3]. Тому, соціокультурний підхід до тлумачення соціально анімації міг призвести до заниження експертами ролі анімаційної функції у діяльності майбутніх фахівців.

Інша частина професійних функцій соціального педагога оцінена більш рівномірно та, як видно на рис. 1., утворює найширше коло із середнім показником актуальності 4,41 бали.

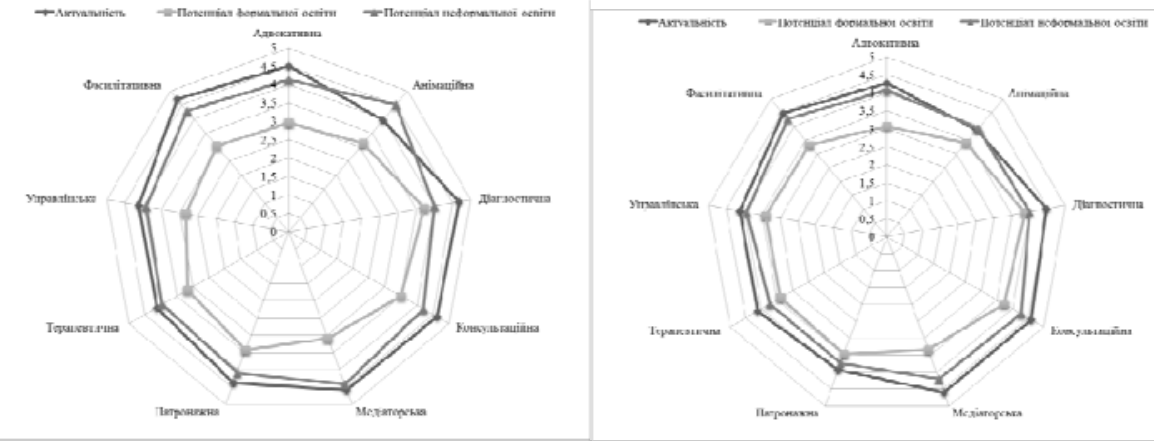

Рис. 1. Підготовка майбутніх соціальних педагогів до виконання професійних функцій, наукова та соціальна експертизи 
Щодо потенціалів формальної і неформальної освіти у професійній підготовці майбутніх соціальних педагогів до виконання означених функцій - то тут ситуація дещо інша. Потенціал неформальної освіти, згідно з оцінками експертів, наближається до актуальності формування професійних функцій майбутніх соціальних педагогів із середнім балом 4,17. За окремими функціями наближення є максимальним (наприклад, управлінська, терапевтична, медіаторська), за анімаційною функцією - навіть перевищує очікування експертів. Найвища різниця актуальності $(4,67)$ та потенціалу неформальної освіти $(4,00)$ спостерігається за діагностичною функцією, що визначає потреби у професійній підготовці майбутніх фахівців із поглибленням власне технологій діагностики та оцінки соціальних явищ.

Натомість, потенціал формальної освіти експерти оцінили значно нижче, середній бал становить 3,20. Власне, потенціал формальної і неформальної освіти наближається лише за шкалою "Діагностична функція"; переважна частина функцій мають значний розрив між потенціалами неформального та формального видів навчання (зокрема, адвокативна, фасилітативна, управлінська, медіаторська функції). Тобто, результати експертної оцінки засвідчили переваги неформальної освіти перед формальною, які ми вбачаємо, передусім у мотиваційному та організаційному аспектах забезпечення якості навчання. Наявна соціальна ситуація реформування вищої освіти сьогодні вимагає зміни концептуальних підходів до ії організації з виділенням пріоритетів мотивації до професійної діяльності у соціальній сфері, використанням діалогічних методів навчання, побудови індивідуальної траєкторії фахового розвитку майбутніх соціальних педагогів із урахуванням їх інтересів і потреб. Саме це, на нашу думку, відображає наявну ситуативну перевагу неформальної освіти над формальною та потребує інновацій у формальній освітній системі.

Результати соціальної експертизи частково повторюють тенденцію опитування експертів-науковців (див. табл. 4): переважання актуальності формування професійних функцій над потенціалом освіти. Водночас, аналіз середніх оцінок свідчить про переважання балів формальної освіти $(3,44)$ над актуальністю $(4,27)$ і потенціалом неформальної освіти $(4,01)$. Тобто, у оцінках соціальної експертизи, в порівнянні з науковою, значно менший розрив між загальними балами за трьома шкалами.

Табличя 4.

Соціальна експертиза функціональної моделі майбутніх соціальних педагогів

\begin{tabular}{|c|c|c|c|c|}
\hline № & Функиії & Актуальність & $\begin{array}{c}\text { Потенціал } \\
\text { формальної } \\
\text { освіти }\end{array}$ & $\begin{array}{c}\text { Потениіал } \\
\text { неформальної } \\
\text { освіти }\end{array}$ \\
\hline 1 & Адвокативна & 4,27 & 3,07 & 4,07 \\
\hline 2 & Анімаційна & 3,87 & 3,40 & 3,93 \\
\hline 3 & Діагностична & 4,47 & 3,87 & 4,00 \\
\hline 4 & Консультаційна & 4,60 & 3,73 & 4,27 \\
\hline 5 & Медіаторська & 4,60 & 3,33 & 4,20 \\
\hline 6 & Патронажна & 3,93 & 3,47 & 3,73 \\
\hline 7 & Терапевтична & 4,13 & 3,40 & 3,73 \\
\hline 8 & Управлінська & 4,13 & 3,40 & 3,93 \\
\hline 9 & Фасилітативна & 4,47 & 3,33 & 4,27 \\
\hline & Середнє & 4,27 & 3,44 & 4,01 \\
\hline
\end{tabular}

У функціональній моделі професійної підготовки майбутніх соціальних педагогів найнижче оцінено актуальність анімаційної $(3,87)$ та патронажної $(3,93)$ функцій; найвище - консультаційної та медіаторської (по 4,60 бали). Дані соціальної експертизи, на нашу думку, відображають очікування суспільства від фахівців соціальної сфери. I одержані оцінки свідчать про потреби у забезпеченні клієнтів соціальної допомоги передусім якісними посередницькими послугами (як-от консультування та медіація). На нашу думку, це може дещо звужувати сферу професійної діяльності соціальних педагогів яких часто розглядають як "додаткових" фахівців у системній взаємодії "учитель - учень - батьки". Це не дозволяє враховувати автономність соціально-педагогічної діяльності, коли власне соціальний педагог може бути експертом у наданні соціально значущих функцій діагностики, адвокації, терапії, менеджменту та ін.

За результатами соціальної експертизи, роль формальної освіти у формування фахових функцій оцінена вище, але, як видно з рис. 1, вона однаково поступається потенціалу неформальної освіти. Ми пояснюємо це емпіричним досвідом експертів (зокрема, їх участю у неформальній освіті) й відповідним розумінням важливості залучення усіх учасників до формування змісту та методів професійного навчання. 
Узагальнені дані експертного оцінювання функціональної моделі майбутніх соціальних

Таблиия 5. педагогів

\begin{tabular}{|l|l|c|c|c|}
\hline № & \multicolumn{1}{|c|}{ Функції } & Актуальність & $\begin{array}{c}\text { Потенціал } \\
\text { формальної } \\
\text { освіти }\end{array}$ & $\begin{array}{c}\text { Потениіал } \\
\text { неформальної } \\
\text { освіти }\end{array}$ \\
\hline 1 & Адвокативна & 4,41 & 3,00 & 4,10 \\
\hline 2 & Анімаційна & 3,92 & 3,23 & 4,28 \\
\hline 3 & Діагностична & 4,59 & 3,77 & 4,00 \\
\hline 4 & Консультаційна & 4,62 & 3,59 & 4,23 \\
\hline 5 & Медіаторська & 4,59 & 3,18 & 4,33 \\
\hline 6 & Патронажна & 4,21 & 3,44 & 3,95 \\
\hline 7 & Терапевтична & 4,13 & 3,26 & 3,87 \\
\hline 8 & Управлінська & 4,13 & 3,05 & 3,92 \\
\hline 9 & Фасилітативна & 4,62 & 3,15 & 4,28 \\
\hline \multicolumn{2}{|c|}{ Середнє } & 4,36 & 3,30 & 4,11 \\
\hline
\end{tabular}

Узагальнення результатів опитування двох груп експертів дозволяє відобразити функціональну модель майбутніх соціальних педагогів комплексно, з урахуванням думки як науковців, так і активістів соціальної сфери. Відповідні дані показано у табл. 5 та на рис. 2.

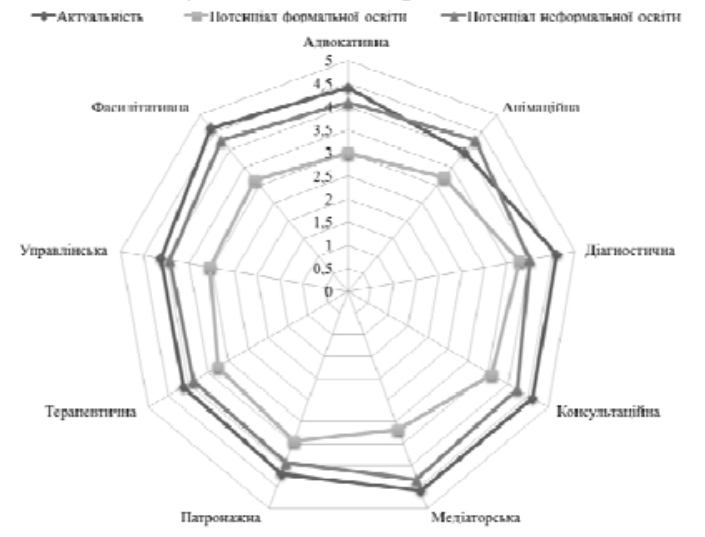

Рис. 2. Підготовка майбутніх соціальних педагогів до виконання професійних функцій, загальні дані

Таким чином, експертиза функціональної моделі професійної підготовки майбутніх соціальних педагогів засвідчує актуальність потреби формування досвіду виконання соціально-педагогічних функцій майбутніми фахівцями. Водночас, результати експертного оцінювання визначають неспроможність забезпечення виконання соціально-педагогічних функцій системою формальної професійної освіти. Натомість, роль неформальної освіти оцінена експертами значно вище (див. рис. 2.), iii оцінка наближається до очікуваного рівня компетентності студентів. Ми пояснюємо це гнучкістю неформальної освіти, іiі адаптивністю до соціальних змін й індивідуальних практичних запитів студентської молоді, орієнтованістю на використання практико орієнтованих технологій навчання (як-от: навчання на прикладі, майстерня майбутнього, рівний навчає рівного та ін.).

Представлені результати експертного опитування дають нам можливість сформулювати такі висновки. Набули емпіричного підтвердження умови результативності неформальної освіти майбутніх соціальних педагогів, до яких відносимо: практико-орієнтованість як відповідність фаховим потребам та надання інструментів для підвищення ефективності діяльності; постійність, системність і неперервність впливу на особистісне й професійне зростання учасників, зумовлене забезпеченням потреби у позитивному самосприйнятті, самоповазі, саморозвитку; поглиблення змісту неформальної освіти 3 опорою на інтереси молоді при іiі організації. Перспективи подальших досліджень убачаємо в дослідженні думки студентської молоді щодо освітніх запитів та впливу різних видів освіти на процес професійного становлення.

\section{СПИСОК ВИКОРИСТАНИХ ДЖЕРЕЛ ТА ЛІТЕРАТУРИ}

1. Павлик Н. П. Зміст і програма експертного оцінювання ролі неформальної освіти у фаховій підготовці майбутніх соціальних педагогів / Н. П. Павлик // Вісник Житомирського державного університету імені Івана Франка. - 2016. - №1 (83). - С. 100-104. 
2. Тобто. Абетка неформальної освіти, фасилітації і тренерства / Ред.-упоряд. Наталія Трамбовецька. - К. : Інша освіта, 2017. - 52 c.

3. Зоська Я. В. Соціальна анімація як соціальна технологія сприяння реалізації особистісного потенціалу молоді на ринку праці / Я. В. Зоська, Н. В. Яцук // Соціологія і психологія праці та зайнятості. - 2015 - №2. - С. 48-51.

\section{REFERENCES (TRASLATED \& TRANSLITERATED)}

1. Pavlyk N. P. Zmist i prohrama ekspertnoho otsiniuvannia roli neformal'noi osvity u fakhovii pidhotovtsi maibutnikh sotsialnykh pedahohiv [The Content and Experts' Evaluation Program Role of Informal Education in Prospective Social Teachers' Training] / N. P Pavlyk // Visnyk Zhytomyrskoho derzhavnoho universytetu imeni Ivana Franka [Zhytomyr Ivan Franko State University Journal]. - 2016. - № 1 (83). - S. 100-104.

2. Tobto. Abetka neformal'noi osvity, fasylitatsii i trenerstva [That Is. Abbreviation of Non-Formal Education, Facilitation and Coaching] / Red.-uporiad. Nataliia Trambovetska. - K. : Insha osvita, 2017. - $52 \mathrm{~s}$.

3. Zoska Ya. V. Sotsial'na animatsiia yak sotsial'na tekhnolohiia spryiannia realizatsii osobystisnoho potentsialu molodi na rynku pratsi [Social Animation as a Social Technology to Promote the Implementation of the Personal Potential of Youth in the Labor Market] / Ya. V. Zoska, N. V. Yatsuk // Sotsiolohiia i psykholohiia pratsi ta zainiatosti [Sociology and Psychology of Labour and Employment]. - 2015 - № 2. - S. 48-51.

\section{Павлик Н. П. Экспертная оценка результативности неформального образования в профессиональной подготовке будущих социальных педагогов.}

В статье представлень результаты экспертного оценивания роли неформального образования 8 профессиональной подготовке будущих сочиальных педагогов по шкалам: значение неформального

образования в профессиональном становлении экспертов; определение эффективности форм и методов неформального образования; характеристика обеспечения формирования функциональной модели будущих специилистов социальной сферы. Сформулирован вывод об эмпирическом подтверждении научно обоснованных характеристик неформального образования: практико-ориентированности, постоянности, непрерывности влияния.

Ключевые слова: неформальное образование, экспертная оченка, экспертиза, функциональная модель, будущие сочиальные педагоги.

\section{Pavlik N. P. Expert Assessment of the Non-Formal Education Progress in the Training of Perspective Social Educators.}

The problem of the progress assessment of non-formal education of perspective social educators is determined by the need for empirical study of the role, forms, methods and implementation capabilities of non-formal education in the process of perspective professionals training. The article presents the expert assessment results of the role of non-formal education in the professional training of perspective social educators based on the following scales: the importance of non-formal education in the professional development; determining the effectiveness of non-formal education forms and methods; the characteristics of developing the perspective specialists functional model in the social sphere. Methods of investigation: expert assessment (professionals with sufficient work experience in the field of non-formal education and training experience of perspective specialists in the social sphere, professionals with a number of scientific and popular-scientific publications on the research issue, professionals with a high level of social and public activity, who present different regions of Ukraine), comparative analysis of the participants survey results in scientific and social expertise.

As a result of empirical study, it has been stated that the influence of non-formal learning on the development of practical sphere, directed on the formation of habits, skills and experience, was highly evaluated by the experts.

The second place is presented with the influence of non-formal education on the capability to continuous personal growth as an opportunity to meet the needs of personal growth, development and self-improvement. The prevalence of non-formal education assessment regarding the perspective social educators formal training in the context of forming their ability to carry out professional functions has been also established.

The conclusion on the empirical confirmation of scientifically stated characteristics of non-formal education has been formulated: 1) practical orientation as the correspondence to the professional needs and provision of tools

for improving performance efficiency; 2) consistent and continuous influence on the participants personal growth, conditioned by providing the participants' needs in positive self-perception, self-esteem and selfdevelopment. As a result of the investigation, the importance of extending the content of non-formal education and its support of the youth interests in its organization has been determined.

Key words: non-formal education, expert assessment, expertise, a functional model, perspective social educators. 